\title{
Chromosome and Nuclear Phenotype in the Legume Lathyrus sativus $L$.
}

\author{
S. C. Verma \\ Department of Botany, Punjab University, Chandigarh-160014, India \\ and \\ D. Ohri \\ National Botanic Gardens, Lucknow, India
}

Received May 17, 1977

The legume Lathyrus sativus L. (grass-pea, 'Khesari'), is cultivated in many parts of the world particularly India as a seed crop and for fodder and green manure (Uphof 1959, Chopra et al. 1965, Maheshwari and Singh 1965). It occurs also as a weed, usually of arable lands, and is reported to occur wild in N. India from Bengal plains to Kumaon hills (Hooker 1879). Several workers have already reported on the cytology of the species which reveal differences in the karyotype between cultivars and between natural populations (Table 2). The differences include chromosome morphology and total chromosome length, both involving evolutionary implications (see Roy and Singh 1967, Fouzdar and Tandon 1975). Since differences in chromosome morphology could be developmental and/or influenced by environment and procedure (see Bennett and Rees 1969), it is therefore, desirable to inquire into the validity of intraspecific variation in chromosome phenotype of $L$. sativus, following a uniform procedure and involving a large sample. A systematic enquiry has been made on some eleven cultivars and three local rural populations to reveal the nature and extent of chromosomal diversity with in the species, and also, to interpret the number of nucleolar chromosomes in the complement.

\section{Material and methods}

A total of eleven cultivars and three rural populations from Chandigarh are studied. The list of the materials investigated is given in Table 1. The distilled water-soaked seeds were sown on moist filter paper at room temperature $\left(22^{\circ} \mathrm{C} \pm 2\right)$. In the first phase of the experiments, the root tips were excised when about $1 \mathrm{~cm}$ in length (two to four days from sowing), whereas in the second phase involving only four cultivars (Table 1) the root tips were harvested on the sixth or seventh day from sowing, when they were about $3-4 \mathrm{~cm}$ in length. The uniformity, both ways was necessitated owing to known effects of age (and nutrition) on chromosome phenotype (Bennett and Rees 1969, Bennett 1970). A uniform standard pretreatment of $0.002 \mathrm{M}$ aq. solution of 8-hydroxyquinoline was given at approxi- 
mately $15-16^{\circ} \mathrm{C}$ for three hours (Tjio and Levan 1950). In some cases, for the sake of comparison, untreated root tips or the ones pretreated with 0.05 or 0.2 per cent-colchicine for three hours were also used. Pretreated root tips were thoroughly washed and fixed in 1:3 acetic alcohol for at least twenty four hours, hydrolysed at $60^{\circ}$ in $\mathrm{N} \mathrm{HCl}$ for ten minutes and stained with Feulgen for thirty minutes (Darlington and La Cour 1960). In order to intensify the stain the root tips were squashed in 1 per cent acetocarmine. The slides were made permanent following the standard procedure.

Table 1. The material

\begin{tabular}{|c|c|c|}
\hline No. & Material & Source \\
\hline 1. & $+* \quad B R-13$ & Ag. Res. Stn., Sabour \\
\hline 2. & * $\quad \mathrm{P}-280$ & Genet. Div., IARI, Delh \\
\hline 3. & $\mathrm{~T} 2-12$ & Genet. Div., IARI, Delhi \\
\hline 4. & +* Local Desi & Darbhanga (Bihar) \\
\hline 5. & Rewa-1 & Genet. Div., IARI, Delhi \\
\hline 6. & Rewa-2 & " \\
\hline $7 \because:$ & $+* \quad$ RI T6 Tr. $90 / 70$ & " \\
\hline 8. & RI T6 Tr. III/70 & $"$ \\
\hline 9. & LC-76 & , \\
\hline 10. & $\mathrm{LC}-76 / 70$ & $"$ \\
\hline 11. & +* Comm. Variety & Hazaribagh (Bihar) \\
\hline 12. & Chandigarh-I & Agrestal (wheat field) \\
\hline 13. & Chandigarh-II & Agrestal \\
\hline 14. & Chandigarh-III & Agrestal \\
\hline
\end{tabular}

+ Cultivars used for the 2nd phase of detailed study.

* Cultivars used at Aberystwyth (U.K.) for chromosome phenotype and DNA measurements.

A third set of observations on five materials, were made by the senior author (SCV) at Aberystwyth (U.K.), where seeds were grown in vermiculite moistened with distilled water. Root tips were picked on the third or fourth day, pretreated with 0.2 per cent colchicine for three hours and fixed in 1:3 acetic alcohol. Feulgen-stained root tips were squashed in 45 per cent acetic acid. The cover slips were removed on dry ice and the slides were mounted in euparal, subsequent to two changes in absolute alcohol.

Chromosome measurements were taken from drawings and photographs made from temporary slides, and in some cases (at Aberystwyth) with the aid of Vicker's moving scale micrometer. Idiograms are prepared on $1 \mathrm{~mm}$ sq. graphs paper by showing the centromere as a $2 \mathrm{~mm}$ gap and the secondary constriction as a $4 \mathrm{~mm}$ gap. Chromosome volumes are calculated by considering the chromatids as cylinders. Measurements of total chromatin length in each variety is based on

Figs. 1-6. Magnification. $\times 1400$. 1, chromosomes at mid prophase showing a gradient of condensation, being more condensed near the centromere than at distal ends. Note 2 big and 2 small fragments. 2, interphase nucleus of cv. RIT6. III/70 showing darkly stained dots. 3, late prophase of cv. BR-13 showing 2 large and 2 small fragments along with 14 chromosomes. 4, a PMC of cv. Rewa-1 showing $7 \mathrm{II}$ (note absence of any fragments). 5, pollen mitosis showing 2 SAT-chromosomes one with larger and the other with smaller satellite. 6, a PMC of cv. Local Desi at diakinesis showing $2 \mathrm{II}$ attached to a nucleolus. 


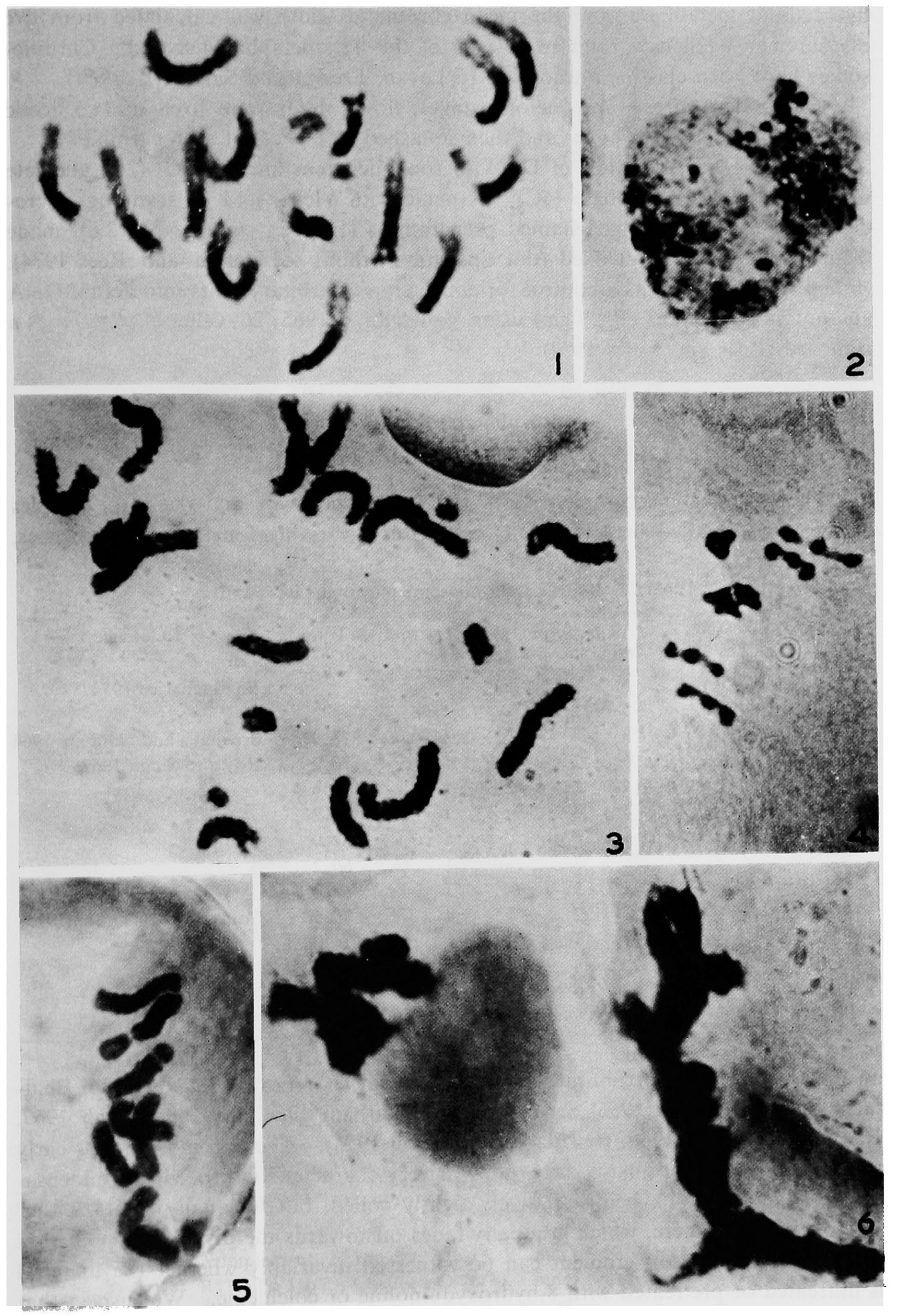


five cells at metaphase, and the mean chromatid width was calculated from five measurements taken at random in each of the five metaphases scored. Chromosomes have been classified according to Levan, Fredga and Sandberg (1964).

For pollen mitosis and meiotic stages, flower buds were fixed in 1:3 acetic alcohol for twenty four hours and then squashed in 1 per cent acetocarmine.

Photometric estimation of DNA in root meristem nuclei at $\mathrm{G}_{1}(2 \mathrm{C})$ and late interphase to early prophase (4C) was made with Vicker's $M 85$ scanning microdensitometer from Feulgen-stained preperations (Feulgen stain at $\mathrm{pH}$ 3.6), made from non-pretreated but fixed root tips (for methods see Verma and Rees 1974). Allium cepa was used as a control for conversion of arbitary units into actual DNA amount in picograms $\left(10^{-12} \mathrm{gm}\right)$ using Vant Hof's (1965) $2 \mathrm{C}$ value of $A$. cepa as a standard (Rees and Jones 1972).

\section{Results and comments}

\section{Chromosomes at prophase}

The chromosome complement of the various cultivars and the rural samples of L. sativus studied here (Table 1) comprises invariably fourteen chromosomes,

Table 2. Reported chromosome phenotype in L. sativus

\begin{tabular}{|c|c|c|c|c|c|c|}
\hline Material & \multicolumn{3}{|c|}{ Karyotype } & $\begin{array}{l}\text { Pairs with } \\
\text { s.c/sat. }\end{array}$ & $\begin{array}{c}\text { Total } \\
\text { chr.1. }(\mu)\end{array}$ & Reference \\
\hline Agri. Stn. (W.B.) & 6 & 1 & & 3 & & Bhattacharjee 1954 \\
\hline & 5 & 2 & & & & \\
\hline Agri. Stn. Bihar & 3 & 4 & & 4 & 73.4 & Srivatava and Naithani 1964 \\
\hline Local var. (patna) & 5 & 2 & & 1 & 72.2 & Roy and Singh 1967 \\
\hline BR-3 & 5 & 2 & & 1 & 51.6 & ; \\
\hline Comm. Var. & 4 & 3 & & 1 & 58.2 & , \\
\hline $\mathrm{BR}-13$ & 1 & 6 & & 1 & 62.0 & $"$ \\
\hline BR-14 & & 7 & & 1 & 66.2 & ", \\
\hline U.K. & 2 & 5 & & 1 & 69.4 & ", \\
\hline PLK-15A & & 7 & & 1 & 70.54 & Fouzdar and Tandon 1975 \\
\hline PLK-25 & & 4 & 3 & & 74.08 & ", \\
\hline PLK-35 & & 4 & 3 & & 67.92 & $"$ \\
\hline PLK-40A & & 6 & 1 & & 52.12 & , \\
\hline PLK-100 & & 5 & 2 & & 51.24 & $"$ \\
\hline
\end{tabular}

an observation that corroborates, with all the earlier reports (B. Roy 1936, Bhattacharjee 1954, Datta 1955, Srivastava and Naithani 1964, Roy and Singh 1967, Rees and Hazarika 1969, Fouzdar and Tandon 1975). The chromosomes at early to middle and late prophase stages show a very characteristic procentric condensation gradient (Fig. 1), being relatively tightly coiled, but unequally so, on either side of the centromere, which gradually fades off towards the distal parts. Such a prophase condensation gradient can be witnessed invariably whether the material is untreated or pretreated with 8-hydroxyquinoline or colchicine. We suspect that this asynchronous condensation along the length of the chromosomes is suggestive of "heterochromatin". 

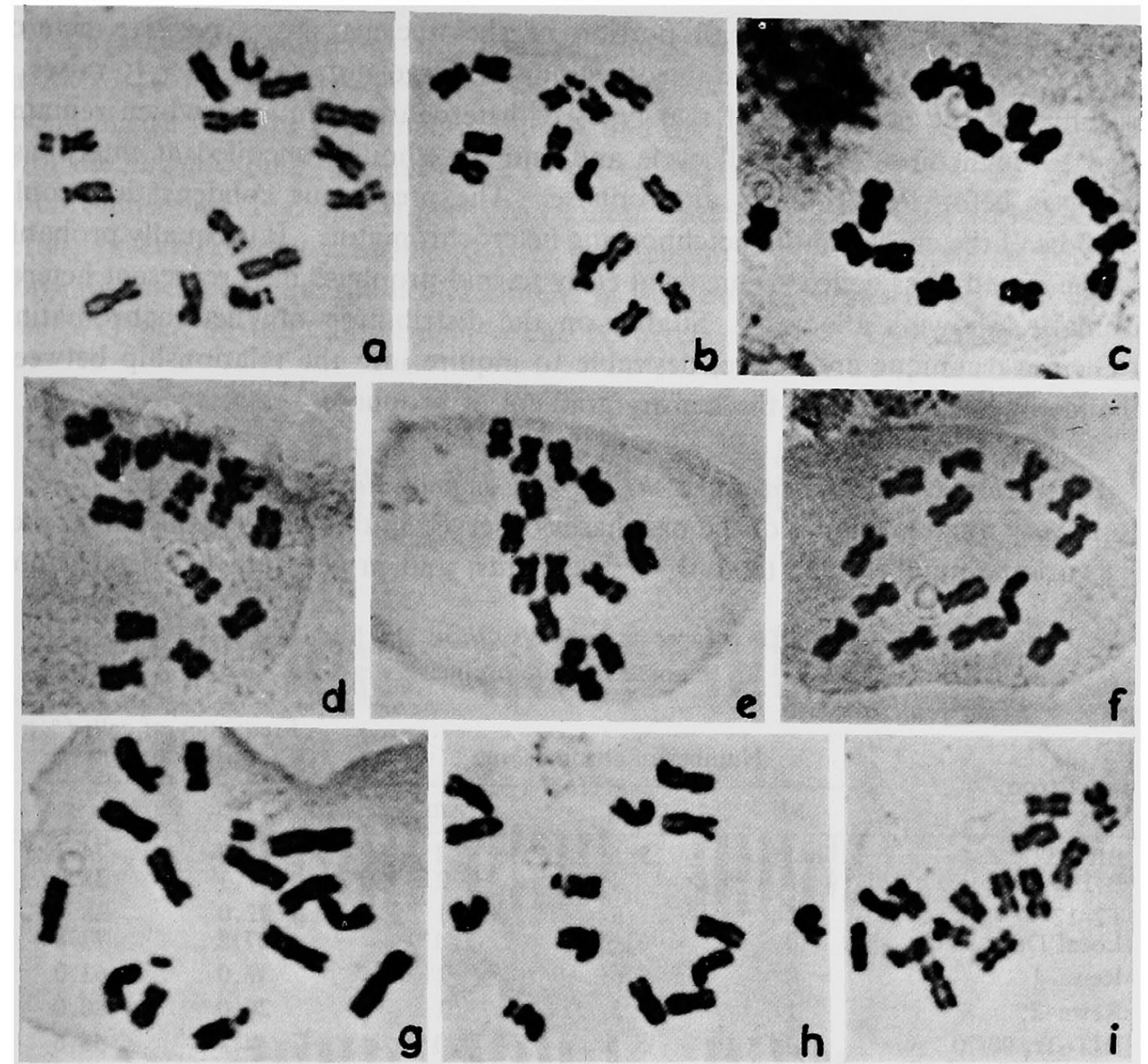

e
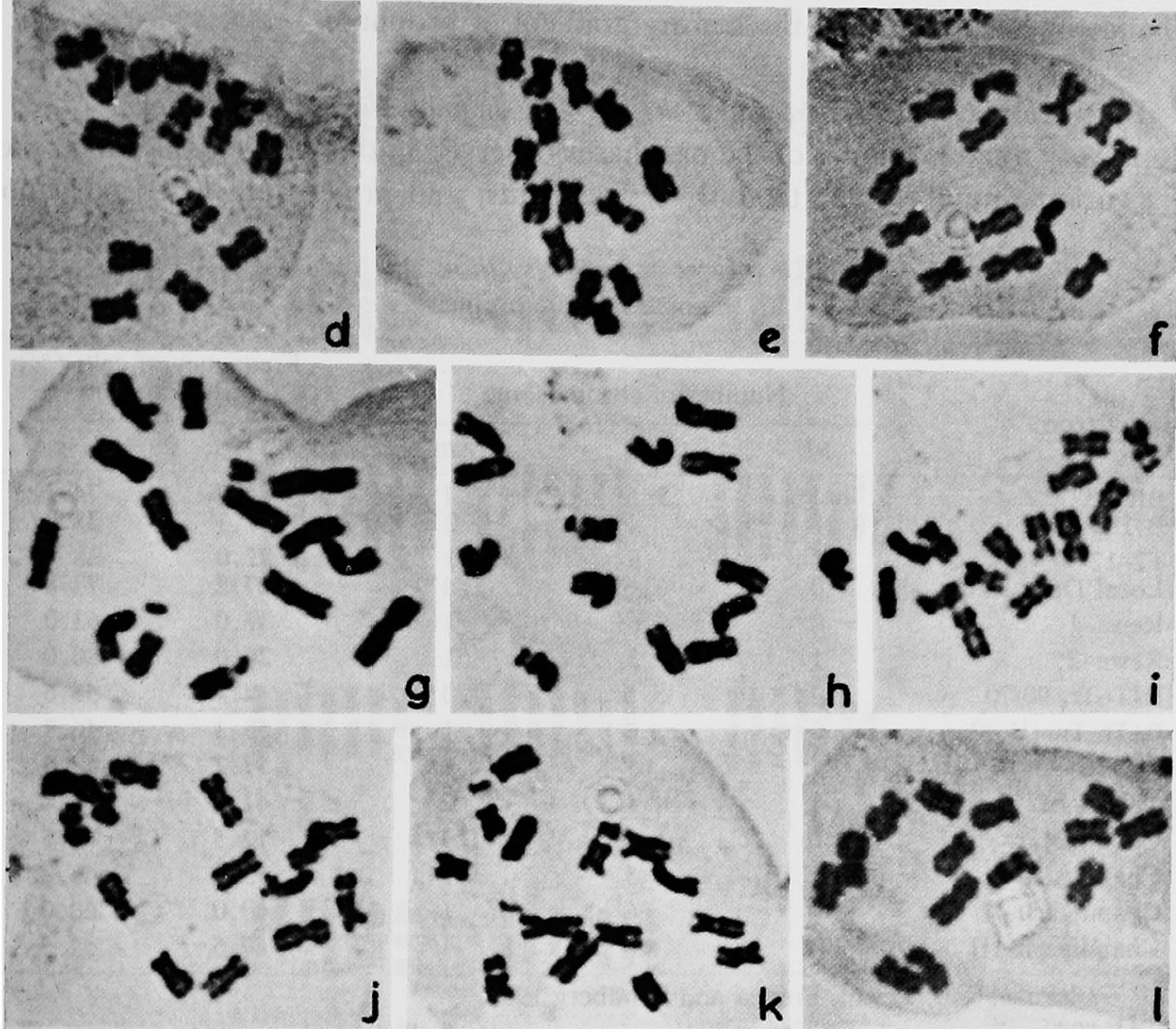

h
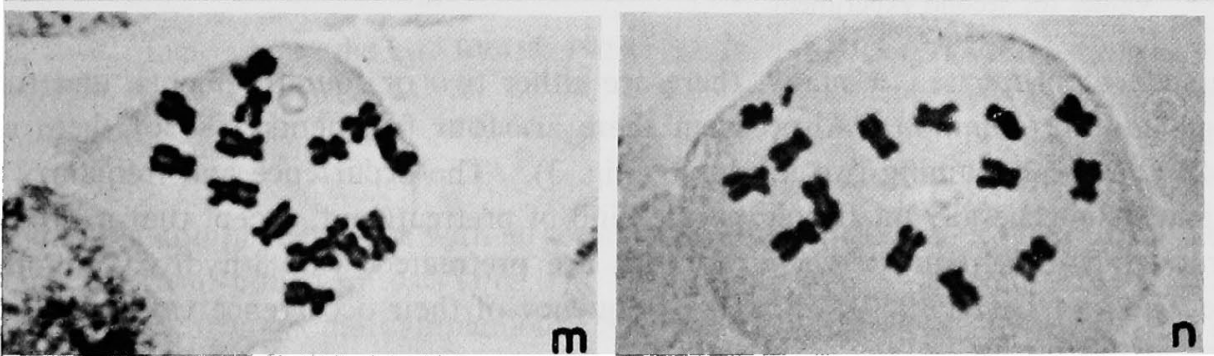

Fig. 7a-n. Mitotic complements of the cvs. BR-13, P-280, T2-12, Local Desi, Rewa-1, Rewa2, RIT6, Tr. 90/70, RIT6 Tr. III/70, LC-76, LC-76/70, Comm. Var., Chandigarh-J, ChandigarhII, Chandigarh-III. $\times 1200$. 
At interphase, only a small portion of the nucleus shows positive heteropycnosis, observed as darkly stained regions or large dots (Fig. 2). It raises a possibility of the occurrence of two types of heterochromatin, one which remains coiled through most of the cell cycle and another, though uncoiled at interphase condenses before euchromatin at prophase. The precocious condensation could as well be of the euchromatin, neighbouring heterochromatin. It is equally probable that the distally less coiled segments at early to mid-prophase may represent heterochromatin, showing allocycly. Studies on the distribution of "heterochromatin" by Giemsa technique are, hence, desirable to inquire into the relationship between C-bands at metaphase and the density gradient at prophase.

2. Fragments during prophase and the number of nucleolar chromosomes

A very notable feature of the prophases observed in this study is the occurrence of a variable number, one to four, of fragments, and in general, it depends upon

Table 3 Karyotype ${ }^{1}$ in Lathyrus sativus and frequency of fragments at late prophase

\begin{tabular}{|c|c|c|c|c|c|}
\hline \multirow{2}{*}{ Taxon } & \multicolumn{3}{|c|}{ Number of chromosome } & \multicolumn{2}{|c|}{$\begin{array}{l}\text { Frequency of cells }(\%) \\
\text { with 'fragments }\end{array}$} \\
\hline & $\mathbf{M}$ & $\mathrm{m}$ & $\mathrm{sm}$ & 2 & 4 \\
\hline $\begin{array}{l}\text { BR-13 } \\
\text { P-280 }\end{array}$ & $1,1_{1}^{*}$ & $5,5_{4}^{*}$ & $1,1_{2}^{*}$ & $\begin{array}{l}25.7 \\
77.3\end{array}$ & $\begin{array}{l}74.3 \\
22.7\end{array}$ \\
\hline $\begin{array}{l}\text { T2-12 } \\
\text { Local Desi }\end{array}$ & $\begin{array}{l}1 \\
0\end{array}$ & $\begin{array}{c}5 \\
6,6^{*}\end{array}$ & $1,1^{*}$ & $\begin{array}{l}72.0 \\
27.2\end{array}$ & $\begin{array}{l}28.0 \\
77.8\end{array}$ \\
\hline Rewa-1 & 0 & 6 & 1 & 37.0 & 63.0 \\
\hline Rewa-2 & 1 & 5 & 1 & 20.0 & 80.0 \\
\hline RIT6Tr. 90/70 & $1,1^{*}$ & $5,5^{*}$ & $1,1^{*}$ & 44.4 & 55.6 \\
\hline RIT6 Tr. III/70 & 0 & 6 & 1 & 53.3 & 46.7 \\
\hline LC-76 & 1 & 5 & 1 & 57.2 & 42.8 \\
\hline$L C-76 / 70$ & 1 & 4 & 2 & 41.6 & 58.4 \\
\hline Comm. Var. & 0 & $6,6^{*}$ & $1,1^{*}$ & 12.5 & 87.5 \\
\hline Chandigarh-I & 1 & 5 & 1 & 53.3 & 46.7 \\
\hline Chandigarh-II & 0 & 6 & 1 & 40.0 & 60.0 \\
\hline Chandigarh-III & 1 & 5 & 1 & 47.5 & 52.5 \\
\hline
\end{tabular}

1 Classification: Levan, Fredga and Sandberg 1964.

* Values for second experiment.

the state of prophase. Usually, there are either two or four fragments, and four fragments are common. Also, when there are four fragments, two of them are small and the remaining two are large (Fig. 3). The occurrence and frequency of fragments is generally unaffected by the kind of pretreatment, except that it is comparatively more frequent when root tips are pretreated with 8-hydroxyquinoline (see Tjio and Levan 1950). But, the frequency of their occurrence varies between varieties (Table 3 ).

The fragments nearly simulate B-chromosomes and can be mistaken for them if stages further than late prophase are not followed. As the chromosomes approach metaphase condensation, the fragments tend to lie close to and in tandem with the arms of particular chromosomes (Figs. 7a-n, 9-12). 
In general, there are no fragments at mitotic metaphase and they never appear in PMC's (Figs. 4, 7a-n, 9-12). The two smaller fragments, at prophase, correspond in size with the prominent satellites, and the two larger fragments correspond with the chromosome segment distal to the secondary constrictions in another pair of chromosomes (Fig. 3). It needs to be emphasized that colchicine pretreated material, reveals generally owing to over condensation, only one pair of satellited chromosomes, with the smaller satellite (Fig. 13), but this is not to say that there is one SAT-pair in the complement. The occurrence of two SAT-chromosomes in

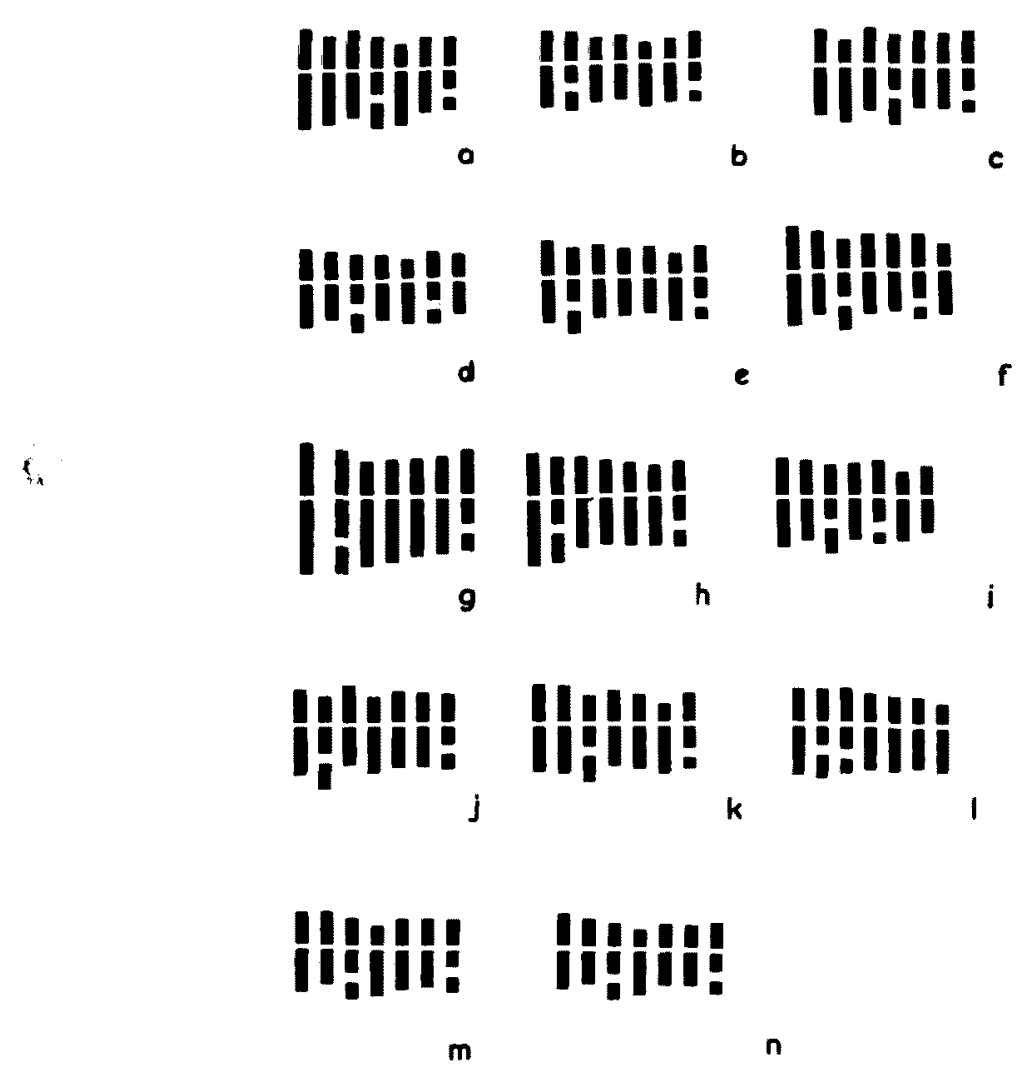

Fig. 8a-n. Idiograms of the cvs. BR-13, P-280, T2-12, Local Desi, Rewa-1, Rewa-2, RIT6 Tr. 90/70, RIT6 Tr. III/70, LC-76, LC-76/70, Comm. Var., Chandigarh-I, Chandigarh-II, Chandigarh-III. $\times 1600$.

the haploid complement, one with larger and the other with smaller satellite, has been confirmed from pollen mitosis (Fig. 5). The inference of two satellitic or nuclolar pairs in the chromosome complement of $L$. sativus is further substantiated by observations at diakinesis in PMC's which show invariably two bivalents attached to a nuclolus (Fig. 6). We, therefore, interpret the occurrence of fragments during prophase as disarticulated chromosome segments beyond the secondary constrictions of both the pairs. The two SAT-pairs are nucleolar in nature. 




Figs. 9-14. 9-12, mitotic complements of the cvs. BR-13, Local Desi, RIT6 Tr. 90/70. Comm. Var. $\times 1400$. 13 and 14, mitotic complements of the cvs. RIT6 Tr. III/70 and T2-12 (pretreated with $0.2 \%$ colchicine). $\times 1400$. 


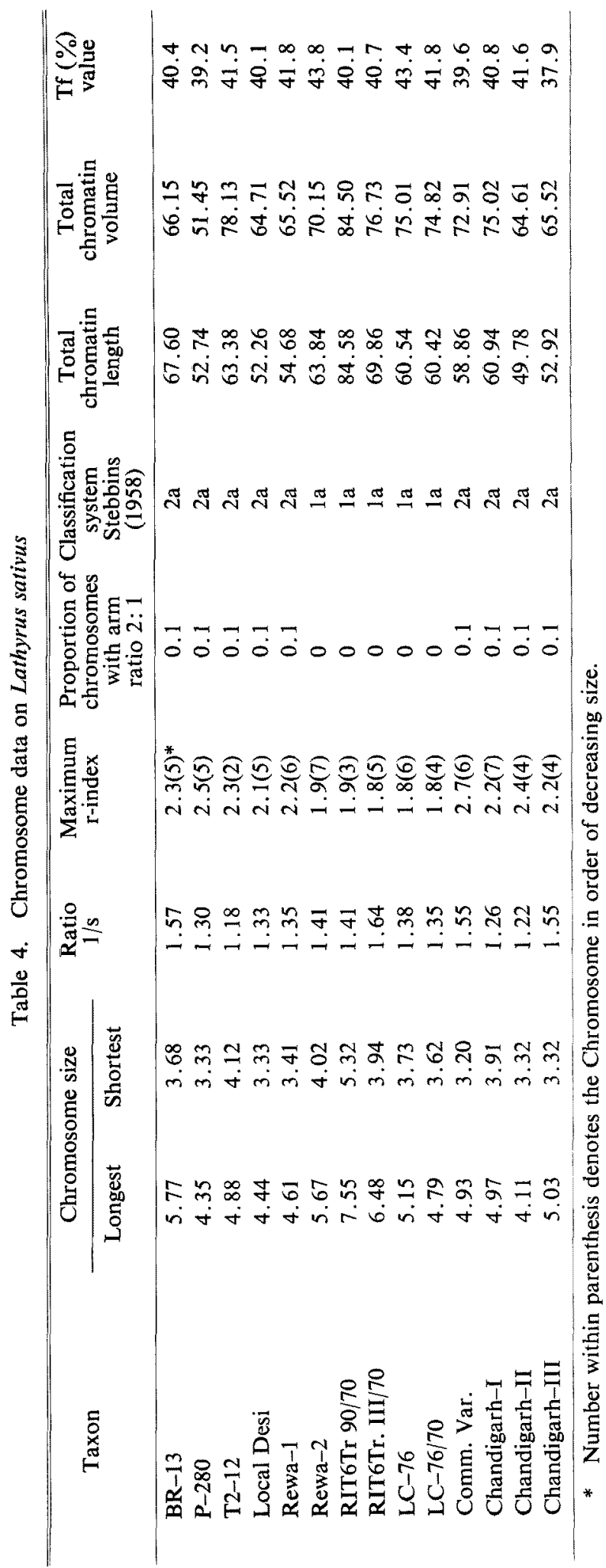




\section{Karyotype variation}

Karyotypes of 11 cultivars and three rural samples are illustrated in Figs. 7a- $n$ and $8 \mathrm{a}-\mathrm{n}$ and tabulated in Tables 4-6. The chromosome complement of 14 strains, when classified following Levan, Fredga and Sandberg (1964) falls karyotypically under three categories i) $0 M+6 m+1 \mathrm{sm}$, ii) $1 M+5 m+1 \mathrm{sm}$ and, iii) $1 \mathrm{M}+4 \mathrm{~m}+2 \mathrm{sm}$ pairs (Table 3 ). The data obtained from the second set involving only four cultivars likewise support the karyotype analysis of the first series, stated above (Tables 3-7, Figs. 9-12). In nine of the 14 strains there is one chromosome pair with median centromere (M, $\mathrm{r}$ index 1.0). A conspicuously common feature between all the forms is one pair of chromosomes with sub-median centromere (sm, $r$ index >1.7). In only two cultivars, P-280 and LC 76/70 there are an additional pair of sub-metacentric chromosomes. The remaining chromosomes in the complement belong to the catagory of metacentric chromosomes.

The magnitude of karyotype asymmetry in various strains of $L$. sativus has been determined by parameters of relative size of chromosomes following the system proposed by Stebbins (1958). The karyotypes analysed presently, fall in la and $2 \mathrm{a}$ categories (Table 4), which means that all the forms have symmetrical karyotypes, but there is perceptible variation between the varieties. The ratio of the longest to the smallest chromosomes of different cultivars ranges between 1.18 (T2-12) and 1.64 (RIT6 Tr. III/70), (Table 4). Nine cultivars have one chromosome pair in the complement with $\mathrm{r}$-index $>2.0$ (Table 4). Tf value (ratio in percentage of the total sum of short arms to the total sum of chromosomes) shows a range between 37.9 (Chandigarh III) and 43.8 (Rewa-2). The most significant component of variation between the varieties is the total chromatin volume, which varies from $51.45 \mu^{3}$ to $84.50 \mu^{3}$ (Table 4). This variation does not alter the Tf value proportionately, which shows that the component of variation in total chromosome volume is more or less uniformly distributed throughout the complement rather than being confined to any particular arms of the chromosomes.

It has already been shown in the preceding section that, in all the varieties, there are invariably 2 pairs of nucleolar chromosomes. These provide suitable markers to detect further karyotypic variation between the varieties, by comparing their relative position in the complement based on decreasing order of size, and the size of the satellites. It is interesting to observe that the size of the satellites varies considerably between the varieties, like the total chromatin length and volume at metaphase (Tables 5,6). Besides, SAT-chromosomes themselves vary with regard to their relative position in the complement. In 11 out of the 14 forms, the SATpair with the smaller satellite is the smallest in the complement (Table 5), and in only 6 forms this SAT-pair is strictly median (M) (Table 5). The nucleolar chromosome with the larger "satellite" is the second largest in the complement in seven cases, third largest in five cases, and fourth largest in two cases (Table 6). In 13 out of 14 forms, this chromosome pair is metacentric (m), and in only one case it is submetacentric (sm) (Table 6).

\section{Total chromatin length (TCL), volume (TCV) and DNA content}

The first series of experiment involving 14 strains (cult. and wild) shows 
Table 5. Values of different chromosome segments in case of chromosomes with smaller satellite

\begin{tabular}{lccccc}
\hline \multicolumn{1}{c}{ Taxon } & $\begin{array}{c}\text { Total } \\
\text { length of } \\
\text { chromosome }\end{array}$ & $\begin{array}{c}\text { Mor- } \\
\text { phology }\end{array}$ & $\begin{array}{c}\text { Length of } \\
\text { short arm }\end{array}$ & $\begin{array}{c}\text { Length of } \\
\text { long arm } \\
\text { (excl.satellite) }\end{array}$ & $\begin{array}{c}\text { Length of } \\
\text { satellite }\end{array}$ \\
\hline BR-13 & $3.67(7)$ & $\mathrm{M}$ & 1.82 & 1.11 & 0.75 \\
P-280 & $4.43(7)^{*}$ & $\mathrm{M}^{*}$ & $2.18^{*}$ & $1.42^{*}$ & $0.83^{*}$ \\
T2-12 & $3.33(7)$ & $\mathrm{M}$ & 1.60 & 1.11 & 0.62 \\
Local Desi & $4.12(7)$ & $\mathrm{M}$ & 2.0 & 1.37 & 0.75 \\
& $3.45(7)$ & $\mathrm{m}$ & 1.55 & 1.06 & 0.84 \\
Rewa-1 & $5.25(7)^{*}$ & $\mathrm{~m}^{*}$ & $2.45^{*}$ & $1.74^{*}$ & $1.06^{*}$ \\
Rewa-2 & $3.41(7)$ & $\mathrm{m}$ & 1.60 & 1.15 & 0.66 \\
RIT6 Tr. 90/70 & $4.21(6)$ & $\mathrm{m}$ & 1.95 & 1.55 & 0.71 \\
& $5.32(7)$ & $\mathrm{M}$ & 2.66 & 1.46 & 1.20 \\
RIT6 Tr. III/70 & $5.59(7)^{*}$ & $\mathrm{M}$ & $2.71^{*}$ & $1.60^{*}$ & $1.28^{*}$ \\
LC-76 & $3.94(7)$ & $\mathrm{m}$ & 1.73 & 1.37 & 0.84 \\
LC-76/70 & $4.16(5)$ & $\mathrm{M}$ & 2.04 & 1.37 & 0.75 \\
Comm. Var. & $3.62(7)$ & $\mathrm{m}$ & 1.68 & 1.06 & 0.88 \\
& $3.20(7)$ & $\mathrm{m}$ & 1.26 & 1.28 & 0.66 \\
Chandigarh-I & $4.84(7)^{*}$ & $\mathrm{~m} *$ & $2.27^{*}$ & $1.65^{*}$ & $0.92^{*}$ \\
Chandigarh-II & $4.34(3)$ & $\mathrm{M}$ & 2.08 & 1.33 & 0.93 \\
Chandigarh-III & $3.32(7)$ & $\mathrm{m}$ & 1.55 & 1.02 & 0.75 \\
\hline
\end{tabular}

* Values for the second experiment.

Number within parenthesis denotes the chromosome in order of decreasing size.

Table 6. Values of different chromosome segments in case of chromosome with larger satellite

\begin{tabular}{lccccc}
\hline \multicolumn{1}{c}{ Taxon } & $\begin{array}{c}\text { Total } \\
\text { length of } \\
\text { chromosome }\end{array}$ & $\begin{array}{c}\text { Mor- } \\
\text { phology }\end{array}$ & $\begin{array}{c}\text { Length of } \\
\text { short arm }\end{array}$ & $\begin{array}{c}\text { Length of } \\
\text { long arm } \\
\text { (excl. satelite) }\end{array}$ & $\begin{array}{c}\text { Length of } \\
\text { satellite }\end{array}$ \\
\hline BR-13 & $4.97(4)$ & $\mathrm{m}$ & 1.91 & 1.51 & 1.55 \\
P-280 & $5.90(4)^{*}$ & $\mathrm{~m}^{*}$ & $2.64^{*}$ & $1.69^{*}$ & $1.57^{*}$ \\
T-2-12 & $4.60(2)$ & $\mathrm{m}$ & 1.77 & 1.28 & 1.55 \\
Local Desi & $3.80(4)$ & $\mathrm{m}$ & 1.46 & 1.20 & 1.14 \\
& $3.94(3)$ & $\mathrm{m}$ & 1.73 & 1.06 & 1.15 \\
Rewa-1 & $5.86(3)^{*}$ & $\mathrm{~m}^{*}$ & $2.69^{*}$ & $1.49^{*}$ & $1.68^{*}$ \\
Rewa-2 & $4.21(2)$ & $\mathrm{m}$ & 1.64 & 1.24 & 1.33 \\
RIT6 Tr. 90/70 & $4.52(3)$ & $\mathrm{m}$ & 1.73 & 1.37 & 1.42 \\
& $6.48(2)$ & $\mathrm{m}$ & 2.66 & 2.22 & 1.60 \\
RIT6 Tr. III/70 & $6.86(2)^{*}$ & $\mathrm{~m} *$ & $2.83^{*}$ & $2.07^{*}$ & $1.96^{*}$ \\
LC-76 & $5.40(2)$ & $\mathrm{m}$ & 2.26 & 1.46 & 1.68 \\
LC-76/70 & $4.47(2)$ & $\mathrm{m}$ & 1.86 & 1.15 & 1.46 \\
Comm. Var. & $4.67(2)$ & $\mathrm{sm}$ & 1.60 & 1.56 & 1.51 \\
& $4.21(3)$ & $\mathrm{m}$ & 1.55 & 1.20 & 1.46 \\
Chandigarh-I & $6.28(3)^{*}$ & $\mathrm{~m} *$ & $2.45^{*}$ & $1.89^{*}$ & $1.94^{*}$ \\
Chandigarh-II & $4.53(2)$ & $\mathrm{m}$ & 2.0 & 1.11 & 1.42 \\
Chandigarh-III & $3.63(3)$ & $\mathrm{m}$ & 1.42 & 1.24 & 0.97 \\
\hline
\end{tabular}

* Values for the second experiment.

Number within parenthesis denotes the chromosome in order of decreasing size. 
significant variation in TCL and TCV $(P=>0.01)$. The range of variation is from $49.78 \mu$ to $84.58 \mu$ in TCL, and $51.45 \mu^{3}$ to $84.50 \mu^{3}$ in TCV (Table 4) $(\mathrm{P}=>0.01)$.

The second set of experiment involving only four cultivars as a select sample was designed to repeat the observation with particular reference to age of the roots. There was not only the confirmation of the difference between the varieties, but also there was a significant increase in the values of TCL and TCV of each variety over the values obtained in the first series (cf. Tables 4 and 7,8 ). But, the difference between the 4 varieties, in the second series is not significant $(P=<0.05)$, which emphasizes that the potentiality of developmental increase in chromosome size and volume is nearly the same in each variety.

\section{Discussion}

\section{Nucleolar chromosomes: Number and nature}

In all the 14 strains of $L$. sativus, investigated presently, there are invariably two pairs of nucleolar chromosomes, an observation which contrasts with the earlier reports on the species. Bhattacharjee (1954) reported 2 pairs of chromosomes with secondary constriction and a pair with satellite, whereas Srivastava and Naithani (1964) reported four pairs of chromosomes with secondary constrictions, Roy and Singh (1967) have reported only one pair of chromosomes with secondary constricti on, in six strains of L. sativus and Fauzdar and Tandon (1975) could observe one SAT-pair in only one of the five strains studied by them (Table 2).

Table 7. Chromosome data on Lathyrus sativus (second experiment)

\begin{tabular}{|c|c|c|c|c|c|c|c|c|}
\hline \multirow{2}{*}{ Taxon } & \multicolumn{2}{|c|}{ Chromosome size } & \multirow{2}{*}{ Ratio } & \multirow{2}{*}{$\underset{r \text {-index }}{\text { Maximum }}$} & \multirow{2}{*}{$\begin{array}{l}\text { Propor- } \\
\text { tion of } \\
\text { chromo- } \\
\text { somes } \\
\text { with arm } \\
\text { ratio } 2: 1\end{array}$} & \multirow{2}{*}{$\begin{array}{l}\text { Classifi- } \\
\text { cation } \\
\text { system } \\
\text { Stebbins } \\
\end{array}$} & \multirow{2}{*}{$\begin{array}{c}\text { Total } \\
\text { chroma- } \\
\text { tin } \\
\text { length }\end{array}$} & \multirow{2}{*}{$\begin{array}{c}\text { Tf }(\%) \\
\text { value }\end{array}$} \\
\hline & Longest & Shortest & & & & & & \\
\hline BR-13 & 7.01 & 4.43 & 1.57 & $2.1(5)$ & 0.1 & $2 a$ & 89.5 & 40.3 \\
\hline Local Desi & 6.69 & 5.25 & 1.27 & $2.1(6)$ & 0.1 & $2 a$ & 82.5 & 42.6 \\
\hline RIT6 Tr. 90/70 & 7.91 & 5.59 & 1.39 & $1.9(3)$ & 0.1 & $2 a$ & 88.5 & 41.2 \\
\hline Comm. Var. & 7.58 & 4.84 & 1.56 & $2.2(6)$ & 0.1 & $2 a$ & 88.1 & 42.6 \\
\hline
\end{tabular}

2. Karyotype variation, $T C L$ and $T C V$ :

Different authors have reported intervarietal variation in karyotype and TCL (Table 2). Present study not only corroborates these findings (cf. Tables 3-7, Figs. $7 a-n, 8 a-n)$ but also extend to reveal significant difference between the values obtained with a variety at different age of the root meristem (Tables 7,8 ). That age of roots affects the size of the chromosomes and their volume is already known (Bennett and Rees 1969). What is important in the present case is that an upper limit to the increase in TCL and TCV by 6-7th day is nearly the same, at least in four tested as sample (Table 8); the difference between varieties is not significant $(\mathrm{P}=<0.05)$. It is also interesting to observe that, whereas the difference between replicates of second series is not significant the interaction between varieties and replicates is significant at $1 \%$ level. This shows that there is marked effect on TCL 
and TCV of treatments and other experimental conditions. In conclusion both TCL and TCV are affected by age of the roots and variation in treatments and other unidentified experimental conditions.

\section{DNA estimation}

The data obtained for five cultivars, using photometric estimation of Feulgenstained nuclei suggest that there is absolutely no variation between the five cultivars irrespective of the observed variations in their TCL and TCV (Table 8). This is an important observations conforming to the concept of general constancy of DNA in species. The developmental variation in TCL and TCV is, therefore not associated with variations in the DNA content between the varieties (cf. Roy and Singh 1967, Fouzdar and Tandon 1975). Such variations can be due to changes in the protein content. The positive effects of age and nutrition on the chromosome size (TCL and TCV) in root meristems are already known in Secale cereale and Allium cepa (Bennett and Rees 1969) and where the variation is entirely due to protein content.

Table 8. Chromosome volume and nuclear DNA in Lathyrus sativus

\begin{tabular}{|c|c|c|c|c|c|c|c|c|}
\hline \multirow{3}{*}{ Material } & \multirow{2}{*}{\multicolumn{4}{|c|}{$\begin{array}{l}\times \text { chromosome volume }\left(\mu^{3}\right) \\
\text { from root meristem }\end{array}$}} & \multicolumn{4}{|c|}{$\times$ DNA amount (arb, units) } \\
\hline & & & & & \multicolumn{2}{|c|}{$2 \mathrm{C}$ nuclei } & \multicolumn{2}{|c|}{$4 \mathrm{C}$ nuclei } \\
\hline & 3 days $^{1}$ & 4 days $^{2}$ & $\begin{array}{r}6-7 \\
\text { Rep. I }\end{array}$ & $\begin{array}{l}\text { days }^{1} \\
\text { Rep. II }\end{array}$ & Rep. I & Rep. II & Rep. III & Rep. II \\
\hline P-280 & 51.45 & 53.68 & - & - & 62.09 & 63.31 & 125.74 & 126.94 \\
\hline Local Desi & 64.71 & 67.61 & 99.26 & 98.60 & 63.79 & 62.25 & 123.93 & 125.42 \\
\hline $\mathrm{BR}-13$ & 66.15 & 70.37 & 105.56 & 103.52 & 63.15 & 63.43 & 127.76 & 128.56 \\
\hline Comm. var. & 72.91 & 69.85 & 91.60 & 92.60 & 61.89 & 63.09 & 126.18 & 125.46 \\
\hline RIT6 Tr 90/70 & 84.50 & 77.41 & 96.00 & 96.40 & 62.16 & 63.69 & 126.77 & 127.40 \\
\hline \multicolumn{5}{|c|}{ Control for DNA readings: Allium cepa } & 124.16 & 125.53 & 242.20 & 246.98 \\
\hline \multicolumn{9}{|c|}{$2 \mathrm{C}$ DNA in $L$. sativus (from $A$. cepa conversion) is 16.88 picograms } \\
\hline
\end{tabular}

1 Pretreatment 8-OQ. ${ }^{2}$ Pretreatment $0.2 \%$ colchicine.

\section{Summary}

Chromosome studies based on Feulgen-stained squashes of pretreated and untreated root-tips of eleven cultivars and three local weedy populations of Lathyrus sativus L. (f. Leguminosae) have shown consistent variation in the karyotype between the strains. There is also observed considerable variation between the strains as regards total chromosome length and volume at metaphase in root meristems, and this variation is by and large developmental, and this has been confirmed by detailed analysis on four varieties. Further substantiation on the nature of such variation is derived from microdensitometric estimations of nuclear DNA of a sample of four cultivars, showing wide differences in TCV. There is general constancy of nuclear DNA, suggesting that the observed variation in chromosome volume does not involve the genetic material. It could be due to variation in the protein component. 
The prophase chromosomes show precocious condensation of centromeric regions producing a characteristic proximal-distal gradient, suggestive of heterochromatin. Contrary to the earlier reports, the present observations reveal in general 2 SAT-pairs in the complement, one with small satellite and the other with a large chromosome segment distal to the secondary constriction. A very notable feature of cells at prophase is the occurrence of upto 4 fragments, resulting from the disarticulation of the satellites of 2 SAT-pairs, implying weak secondary constrictions.

\section{References}

Barlow, P. W. and Vosa, C. G. 1969. The chromosomes of Puschkinia libanotica during mitosis. Chromosoma 27: 436-447.

Bennett, M. D. and Rees, H. 1969. Induced and developmental variation in chromosomes of meristematic cells. Chromosoma 27: 226-244.

- 1970. Natural variation in nuclear characters of meristems of Vicia faba. Chromosoma 29: 317-335.

Bhattacharjee, S. K. 1954. Cytogenetics of Lathyrus sativus Linn. Caryologia 6: 333-337.

Chennaveeraiah, M.S. and Love, A. 1959. Occurrence of supernumerary chromosomes and chromosome fragments in Aegilops. Can. J. Genet. Cytol. 1: 26-33.

Chopra, R. N., Badhwar, R. L. and Ghosh, S. 1965. Poisonous Plants of India. 2nd ed., I.C.A.R., New Delhi.

Datta, P. C. 1955. Studies on the structure and behaviour of chromosomes of a few species of the genus Lathyrus. Genetica Iber. 7: 85-116.

Darlington, C. D. and La Cour, L. F. 1960. Handling of Chromosomes. 3rd ed. George Allen \& Unwin Ltd.

Fouzdar, A. and Tandon, S. L. 1975. Cytotaxonomic investigations in the genus Lathyrus. The Nucleus 18: 24-33.

Hooker, J. D. 1879. The Flora of British India. Vol. II. L. Reeve and Co. Ltd. Kent, England.

Kapoor, B. M. 1973. Cytology and supernumerary chromosome fragments in Clintonia borealis (Ait) Raf. Caryologia 26: 457-467.

Levan, A., Fredga, K. and Sandberg, A. A. 1964. Nomenclature for centromeric position on chromosomes. Hereditas 52: 201-220.

Markarian, D. and Schulz-Schaeffer, J. 1958. A possible origin of supernumerary fragment chromosomes. J. Hered. 49: 3-7.

Maheshwari, P. and Singh, U. 1965. Dictionary of Economic Plants. I.C.A.R. New Delhi.

Raven, P. H. and Kyhos, D. W. 1965 . New evidence concerning the original basic number of angiosperms. Evolution 19: 244-248.

Rees, H. and Hazarika, M. H. 1969. Chromosome evolution in Lathyrus, Chromosomes Today Vol. II. Editor C. D. Darlington and K. R. Lewis.

- and Jones, R. N. 1972. The origin of the wide species variation in nuclear DNA content. Int. Rev. Cytol. 32: 53-92.

Roy, B. 1936. On the somatic chromosomes in Lathyrus. Cytologia 7: 424-430.

Roy, R. P. and Singh, M. K. 1967. Cytological studies in the genus Lathyrus. J. Cytol. Genet. 2: $128-140$.

Stebbins, G. L. 1958. Longevity, habitat and release of genetic variability in the higher plants. Cold. Spr. Harb. Symp. Quant. Biol. 23: 365-378.

Srivastava, L. M. and Naithani, S. P. 1964. Cytological studies in certain pulses and beans. Cytologia 29: 453-464.

Tjio, J.H. and Levan, A. 1950. The use of oxyquinoline in chromosome analysis. Anales. Estacion Exper. Aula Dei 2: 21-64.

Uphof, J. C. Th. 1959. Dictionary of Economic Plants. J. Cramer, Weinheim.

Van't Hof, J. 1965. Relationship between mitotic cycle duration, $\mathrm{S}$ period duration and the average rate of DNA synthesis in the root meristem of cells of several plants. Exp. Cell Res. 39: 48-58. 